\title{
Concepção de um Modelo de Ponto de Entrega Voluntária de Materiais Recicláveis e a Inclusão Social de Pessoas da Maior Idade
}

\section{Júlia Boni Soares, Carmenlucia Santos Giordano Penteado.}

\section{Resumo}

Este projeto de pesquisa objetivou a concepção de um modelo de PEV para coleta de recicláveis em uma Vila de moradores idosos localizada no município de Limeira, SP.

\section{Palavras-chave:}

pontos de entrega voluntária, coleta seletiva, inclusão social de idosos.

\section{Introdução}

Os catadores desempenham papel fundamental na gestão dos resíduos sólidos, atuando na coleta seletiva, triagem e comercialização dos materiais. Seu trabalho, muitas vezes sob condições precárias, ocorre de forma individualizada, autônoma e dispersa, como também, de forma coletiva, em cooperativas e associações ${ }^{1}$.

A reciclagem depende da coleta seletiva, que envolve a recolha de recicláveis, separados previamente na fonte geradora, e ocorre na modalidade porta a porta, ou através pontos de entrega voluntária (PEV), os quais utilizam recipientes colocados em pontos fixos, onde o cidadão, espontaneamente, deposita os recicláveis ${ }^{2}$.

Neste contexto, esta pesquisa teve como objetivo geral conceber um modelo de PEV em uma Vila de moradores idosos, visando a sua inclusão social. Os objetivos específicos foram os seguintes: (a) Elaborar o projeto do PEV e procedimentos de operação e manutenção do mesmo; (b) Elaborar material de divulgação e conscientização sobre o uso correto da infraestrutura; e, (c) Identificar os potenciais benefícios ambientais e sociais relacionados ao projeto.

\section{Resultados e Discussão}

A Vila Dignidade faz parte de um programa do Governo do Estado de SP, e na cidade de Limeira conta com uma unidade com 22 casas e 26 moradores, todos acima de 60 anos. Como forma de geração de renda extra, os moradores da Vila passaram a comercializar materiais recicláveis, sem no entanto, levar em consideração a segregação dos resíduos na fonte, a divulgação de informações sobre materiais com interesse econômico, e uma organização geral do espaço para o recebimento dos recicláveis. Para o desenvolvimento do projeto, inicialmente foi realizada a caracterização dos materiais recicláveis coletados, a partir da pesagem diária dos mesmos, pelo período de 2 meses (Tabela 1 ).

Tabela 1. Quantidades dos principais materiais recicláveis coletados no período de 2 meses.

\begin{tabular}{|c|c|c|}
\hline Material & Quantidade (kg) & Ganhos $^{1}(\mathrm{R} \$)$ \\
\hline Papel e papelão & 51,75 & 5,17 \\
\hline Tetra pak & 10,86 & 1,08 \\
\hline PET (garrafas) & 22,73 & 18,18 \\
\hline Demais plásticos ${ }^{2}$ & 32,88 & 10,47 \\
\hline Latas de alumínio & 14,46 & 43,38 \\
\hline
\end{tabular}

'Estimativa de arrecadacão $\mathrm{com}$ a venda dos recicláveis, com base em valores informados pela empresa recicladora que compra os materiais.

${ }^{2}$ Os plásticos foram pesados separadamente, e em função das baixas quantidades, os mesmos foram agrupados.

Os materiais coletados em maior quantidade foram: papel, papelão, alumínio, PET, tetra pak e plásticos diversos. Deste modo, foram instalados 6 tambores para a coleta, que posteriormente são acondicionados em bags (Fig. 1). Quando há um montante de 5 bags cheios, uma empresa recicladora retira o material.

Figura 1. Tambores e bags para coleta seletiva.

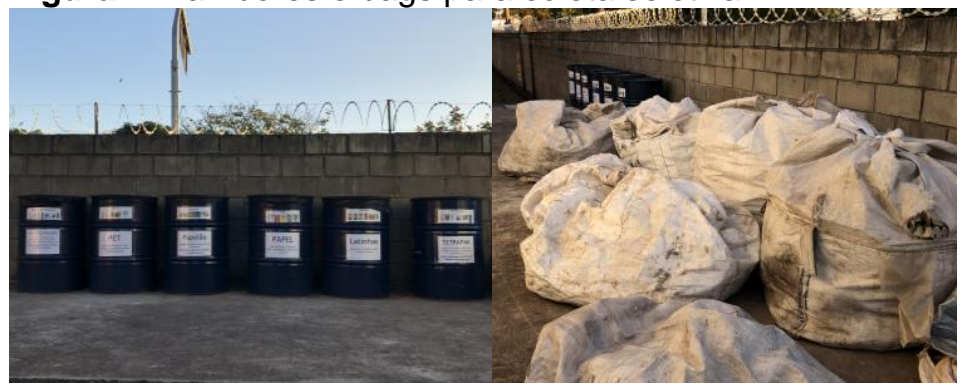

No entanto, há a necessidade de melhorar as condições do PEV, proporcionando um espaço adequado para o acondicionamento dos materiais. Considerando questões técnicas e operacionais, avaliadas ao longo do desenvolvimento da pesquisa, bem a área disponível na Vila, foi elaborado um modelo de PEV (Fig. 2).

Figura 2. Proposta de PEV para a Vila Dignidade.

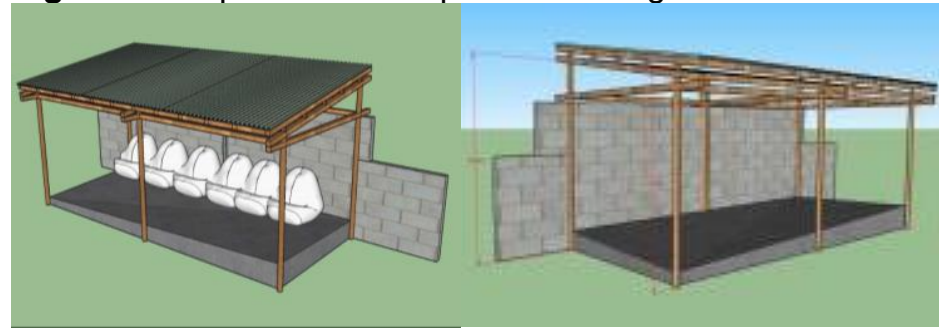

\section{Conclusões}

O projeto de instalação do PEV se mostra viável, no entanto verificou-se a necessidade de um acompanhamento contínuo da sua operação, para garantir o seu bom funcionamento, e a qualidade dos materiais coletados, e com isso, a sustentabilidade econômica da atividade para os moradores da Vila.

\section{Agradecimentos}

À PRP-UNICAMP e ao CNPq pela bolsa, e aos moradores da Vila Dignidade, por possibilitarem 0 desenvolvimento desta pesquisa.

\footnotetext{
${ }^{1}$ Ministério de Meio Ambiente. Catadores de materiais recicláveis. Disponíve em: http://www.mma.gov.br/cidades-sustentaveis/residuos-solidos/catadoresde-materiais-reciclaveis.htm2019.

${ }^{2}$ CEMPRE - Compromisso Empresarial para Reciclagem. Lixo municipal: manual de gerenciamento integrado. 4a ed. São Paulo, 2018.
} 